\title{
Uniformity of tropical micromorphic brachiopods from the Lower Devonian: lingulates from the section Compte-I of Spanish Central Pyrenees
}

\author{
Michal Mergl \& José I. Valenzuela-Ríos
}

\begin{abstract}
Lingulate brachiopods of the Lochkovian and Pragian age from the Compte-I section in the Spanish Central Pyrenees are described to elucidate the evolutionary history of this brachiopod group. Precise bio- and chronostratigraphic position of the brachiopod association is supported by the conodont records, which allows recognition to the threefold Lochkovian subdivision and an approximation of the base of the Pragian. The samples yielded nine taxa, generally poorly preserved and therefore mostly determined only to generic level as Barrandeoglossa, Acrosaccus, Chynithele, Lochkothele, Praeoehlertella, Schizotreta and Havlicekion. This assemblage is similar to micromorphic lingulate brachiopod assemblages from the Lower Devonian in the Barrandian area (Czech Republic) and New South Wales (Australia) confirming hypothesis of general uniformity of micromorphic brachiopods in low latitude periphery the Gondwana palaeocontinent during the Lower Devonian. Dominance of small discinoids, and a glossellid Barrandeoglossa associated to a micromorphic biernatiid Havlicekion $\mathrm{cf}$. holynensis indicates a moderately shallow environment, similar to the one that took place during the deposition of the Kotýs Limestone in the Barrandian area. This interpretation is in agreement with previous palaeoenvironmental inferences for this section based on microfacies studies, Magnetic susceptibility, and Gamma-Ray spectrometry analyses. - Key words: Lingulata, Brachiopoda, Lochkovian, Pragian, Devonian, stratigraphy, Pyrenees, phosphorus cycle.
\end{abstract}

Mergl, M. \& Valenzuela-Ríos, J.I. 2020. Uniformity of tropical micromorphic brachiopods from the Lower Devonian: lingulates from the section Compte-I of Spanish Central Pyrenees. Bulletin of Geosciences 95(2), 215-230 (5 figures, 1 table). Czech Geological Survey, Prague. ISSN 1214-1119. Manuscript received January 20, 2020; accepted in revised form April 15, 2020; published online May 16, 2020; issued May 30, 2020.

Michal Mergl, Centre of Biology and Geosciences, University of West Bohemia, Klatovská 51, 30614, Plzeň, Czech Republic; mmergl@cbg.zcu.cz • José I. Valenzuela-Rios, Department of Botany and Geology, University of Valencia, Dr. Moliner 50, E-46100 Burjasot, Spain

Lochkovian and Pragian strata from selected sections in the Spanish Central Pyrenees have provided one of the best conodont sequences in the world permitting the development and global correlation of hi-resolution bioand chronostratigraphic scales (Valenzuela-Ríos 1990, 1994a, 1994b, 2002; Valenzuela-Ríos \& Murphy 1997; Murphy \& Valenzuela-Ríos 1999; Valenzuela-Ríos et al. 2005; Slavík et al. 2007, 2016; Valenzuela-Ríos \& Liao 2012). This scale is better for the Lochkovian, especially for the middle Lochkovian, but Pragian records in combination with records from the Barrandian area have enabled the proposal of an alternative Pragian conodont biozonation for European sequences (Slavík et al. 2007). Other fossils are not as abundant and have not received much attention, except the ostracods from the Gerri de la Sal sections (Dojen et al. 2009) and some fish remains from the CP-I section (Valenzuela-Ríos et al. 2005).

Lingulate brachiopod remains are present in many conodont samples from Lochkovian and Pragian rocks but commonly they are in low numbers, poorly preserved and with spotty records that difficult a thorough study on this group. However, the section Compte-I (CP-I) presents an excellent record that enables the first systematic study of this group in the Pyrenees and its precise stratigraphical location within a detailed time framework constructed by the accompanying conodont taxa. Therefore, the goals of this paper are (1) to accomplish a systematic study of lingulate brachiopods in the Pyrenean section Compte-I, and (2) place them into the fine biostratigraphic conodont scale for future correlations. The current knowledge of Lower Devonian micromorphic lingulate brachiopods outside Bohemia and Australia is poor and therefore not adequate for correlation and evolutionary suggestion, and any new stratigraphical exactly placed data are of high importance.

\section{Geological setting}

The Compte section is located near the former national road N-260 between the localities of La Pobla de Segur 


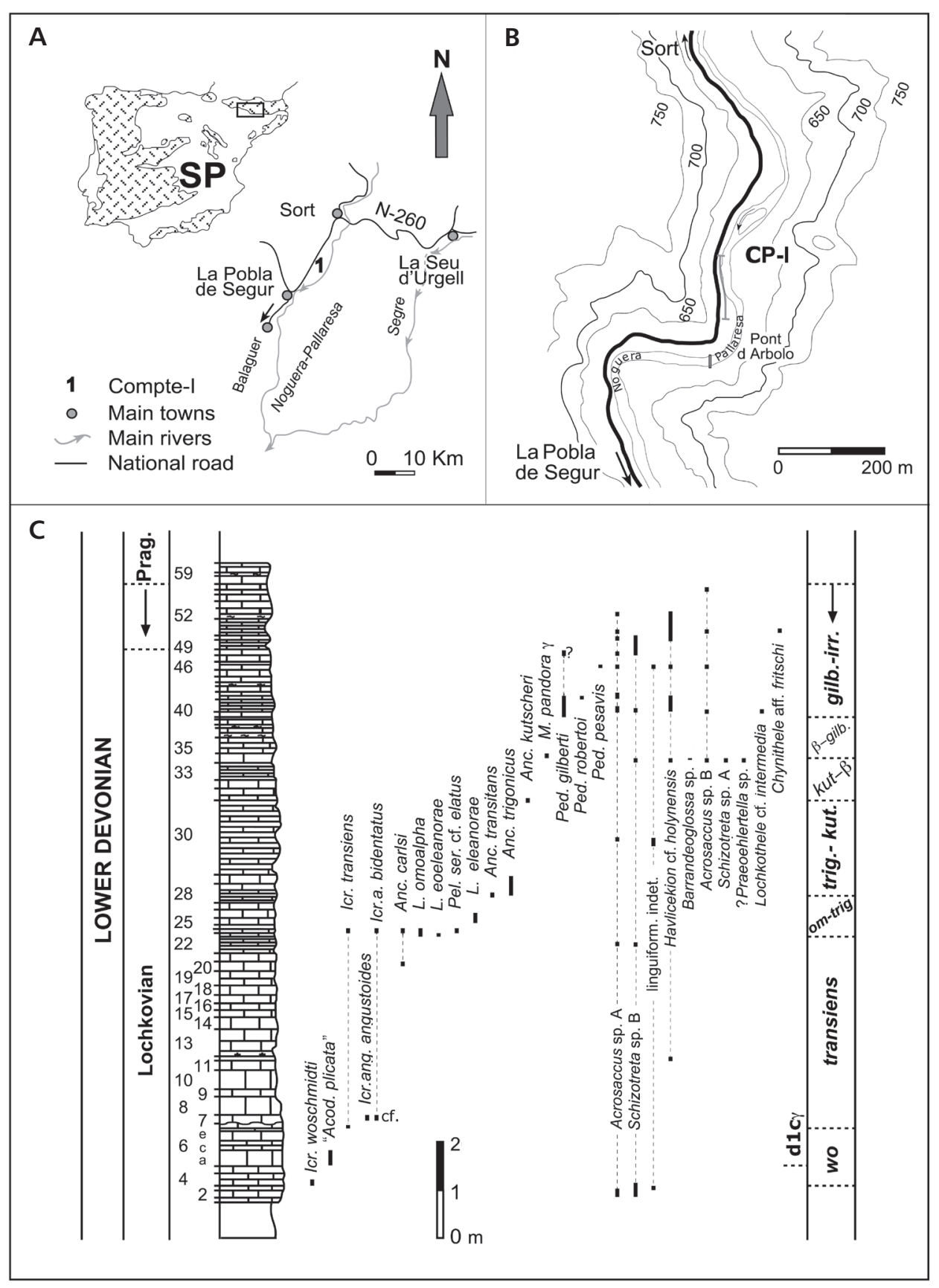

Figure 1. Geographical location of studied section (A and B) and stratigraphical $\log (\mathrm{C})$ with distribution of key conodont taxa and recorded ranges of the brachiopods studied herein referred to the conodont zones (right column) (modified from Valenzuela-Ríos et al. 2017). Abbreviations: SP Spain; CP-I - Section CP-I; Prag. - Pragian; wo - woschmidti Zone; om-trig - omoalpha-trigonicus Zone; the base of this Zone marks the base of the middle Lochkovian according to Valenzuela-Ríos \& Murphy (1997); trig.-kut. trigonicus-kutscheri Zone; kut- $\beta$ - kutscheri-pandora beta Zone; $\beta$-gilberti-pandora beta-gilberti Zone; the base of this zone coincides with the base of the upper Lochkovian (Valenzuela-Ríos \& Murphy 1997); gilb.-irr. gilberti-irregularis Zone; the end of this Zone marks the base of the Pragian; Icr. - Icriodus; Acod. - Acodina; $a$ and ang. - angustoides; Anc. - Ancyrodelloides; L-Lanea; $M$ - Masaraella; Ped. - Pedavis. Conodont records bracket the base of the Pragian between beds 49-55 (see Valenzuela-Ríos et al. 2017)

and Sort, on the right bank of the Noguera Pallaresa River, roughly $1.6 \mathrm{~km}$ north of Gerri de la Sal (Fig. 1A, B) in Spanish Pyrenees. All the fossils come from the Lochkovian and lower Pragian strata of the section Compte-I (CP-I). This section spans the Lochkovian to Emsian (Valenzuela-Ríos et al. 2017), but the betterstudied part is the Lochkovian and early Pragian. Valenzuela-Ríos et al. (2005) described in detail this part of the section and presented the first detailed bioand chronostratigraphic interpretations (Fig. 1C). They identified the three-fold Lochkovian subdivision (lower, middle and upper) and several zones within these parts. Moreover, the Lochkovian/Pragian interval was narrowed for the first time in the Pyrenean sections. Subsequently, Valenzuela-Ríos \& Liao (2012) presented the first general study on thin section and microfacies to characterize the lithofacies present in the CP-I section. Recently, Valenzuela-Ríos et al. (2015) established a conodontbased detailed correlation between the Spanish Central Pyrenees and the Prague Synform for middle and upper Lochkovian strata, including the Lochkovian/Pragian transition in the CP-I section. 


\section{Methods}

Organophosphatic brachiopod described herein were obtained as the side product of the research primarily focused to conodonts. In total, 140 limestone samples were collected and dissolved in diluted formic acid (6$8 \%$ ) for searching conodonts. The insoluble residue was decanted and sieved of $1.5 \mathrm{~mm}$ permitted size separation of larger fragments. The finer residue (smaller than $1.5 \mathrm{~mm}$ ) was dried and brachiopod shells were hand-picked under the binocular lens. Selected brachiopod specimens were on stabs coated by gold and photographed with SEM JSM-6300. Table 1 and Figure 1C show detailed data about distribution of species and number of available specimens.

All the material is housed at the Museum of Geology, University of Valencia (prefix MGUV).

\section{Systematic part}

Order Lingulida Waagen, 1885

Order Lingulida Menke, 1828

Superfamily Linguloidea Menke, 1828

Family Obolidae King, 1846

Subfamily Glossellinae Cooper, 1956

\section{Genus Barrandeoglossa Mergl, 2001}

Type species. - Lingula fissurata Barrande, 1879; Motol Formation, Wenlock, Silurian; Bohemia.

\section{Barrandeoglossa sp.}

Figure 3T

Material. - One fragment, MGUV-36194.

Description. - Small fragment of dorsal valve shows convex smooth larval shell. That is posteriorly bordered by a thickened posterior shell margin forming distinct convex strip tapering toward the apex. Other details are unknown.

Remarks. - Although the material is very poor, the thickened posterior margin is a distinct feature of the genus. The fragment may belong to Barrandeoglossa perneri Mergl, 2001, a common species in the Kotýs Limestone of the Lochkovian age in the Barrandian area of the Czech Republic, but because data about the ventral valve are unknown, an open taxonomical position is preferred.

Occurrence. - Rare in sample CP-I/34 of the Compte-I section.

Table 1. List of samples and brachiopods; numbers of picked specimens and, if determined, the type valve (DV - dorsal valve, VV - ventral valve) are indicated.

\begin{tabular}{|c|c|c|c|c|c|c|c|c|c|c|}
\hline sample & $\begin{array}{c}\text { Barrandeo- } \\
\text { glossa } \mathrm{sp} .\end{array}$ & $\begin{array}{l}\text { Acrosac- } \\
\text { cus sp. A }\end{array}$ & $\begin{array}{l}\text { Acrosac- } \\
\text { cus } \text { sp. B }\end{array}$ & $\begin{array}{l}\text { Chynithele } \\
\text { aff. fritschi }\end{array}$ & $\begin{array}{c}\text { Schizo- } \\
\text { treta sp. A }\end{array}$ & $\begin{array}{c}\text { Schizo- } \\
\text { treta sp. B }\end{array}$ & $\begin{array}{c}\text { PPraeo- } \\
\text { ehlertella sp. }\end{array}$ & $\begin{array}{l}\text { Lochkothele } \\
\text { cf. intermedia }\end{array}$ & $\begin{array}{c}\text { Havlicekion cf. } \\
\text { holynensis }\end{array}$ & $\begin{array}{l}\text { linguliform. } \\
\text { Indet. }\end{array}$ \\
\hline CP-I/02 & & DV (8) & & & & 2 & & & & \\
\hline $\mathrm{CP}-\mathrm{I} / 03$ & & DV (1) & & & & & & & & 1 \\
\hline $\mathrm{CP}-\mathrm{I} / 04 \mathrm{~A}$ & & & & & & 3 & & & & \\
\hline CP-I/12 & & & & & & & & & DV (7), VV (3) & \\
\hline $\mathrm{CP}-\mathrm{I} / 22 \mathrm{~F}$ & & DV (6) & & & & $\mathrm{DV}(2)$ & & & & \\
\hline $\mathrm{CP}-\mathrm{I} / 30 \mathrm{E}$ & & & & & & & & & DV (12) & \\
\hline $\mathrm{CP}-\mathrm{I} / 30 \mathrm{~F}$ & & DV (1) & & & & & & & 3 & \\
\hline CP-I/34 & DV (1) & & DV (1) & & DV (1) & 8 & DV (1) & & DV (4), VV (3) & \\
\hline $\mathrm{CP}-\mathrm{I} / 40 \mathrm{~A}$ & & DV (14) & VV (2) & & & DV (1) & & VV (1) & DV (4), VV (1) & \\
\hline $\mathrm{CP}-\mathrm{I} / 40 \mathrm{C}$ & & DV (12) & & & & DV (1) & & & & \\
\hline $\mathrm{CP}-\mathrm{I} / 41 \mathrm{~A}$ & & DV (9) & & & & & & & 2 & \\
\hline CP-I/41B & & DV (19) & & & & & & & & \\
\hline CP-I/46B & & DV (7) & DV (2) & & & & & & 1 & 1 \\
\hline $\mathrm{CP}-\mathrm{I} / 48$ & & DV (1) & & & & 5 & & & 2 & \\
\hline $\mathrm{CP}-\mathrm{I} / 50$ & & DV (3) & & & & DV (3) & & & 1 & \\
\hline $\mathrm{CP}-\mathrm{I} / 51 \mathrm{~B}$ & & DV (3) & DV (2) & DV (1) & & DV (4) & & & & 1 \\
\hline $\mathrm{CP}-\mathrm{I} / 52 \mathrm{~B}$ & & DV (3) & & & & & & & DV (1) & \\
\hline CP-I/56 & & & DV (1) & & & & & & & \\
\hline CP-IW/51 & & DV (8) & & & & & & & DV (2), VV (4) & \\
\hline CP-IW/51top & & DV (3) & & DV (1) & & & & & & \\
\hline $\mathrm{CP}-\mathrm{IW} / 52 \mathrm{~A}$ & & DV (1) & & & & & & & & 2 \\
\hline CP-IW/52B & & DV (3) & & & & & & & 5 & \\
\hline $\mathrm{CP}-\mathrm{IW} / 52 \mathrm{C}$ & & DV (2) & (DV (2) & & & 2 & & & DV (5), VV (9) & \\
\hline
\end{tabular}


Superfamily Discinoidea Gray, 1840

Family Discinidae Gray, 1840

\section{Genus Acrosaccus Willard, 1928}

Type species. - Acrosaccus schuleri Willard, 1928; Rich Valley Formation, Sandbian, Ordovician; Virginia, USA.

\section{Acrosaccus sp. A}

Figure 2

Material. - A hundred dorsal valves and their fragments, see Tab. 1 (figured specimens MGUV-36171-36183).

Description. - Shell moderately thick-walled, $6 \mathrm{~mm}$ wide in the largest known fragment. The dorsal valves range from elongate elliptical to gently transversally oval outlines (Fig. 2A, B, E, F, G), with some valves nearly circular (Fig. 2C, D, N). Anterior and lateral margins are evenly rounded, the posterior margin is slightly less rounded. Valve convexity is low both in transverse and longitudinal profiles, but the brephic valve is prominently convex and elevated above the adjacent surface of mature shell (Fig. 2L). The apex is situated in posterior $1 / 4$ of the valve. The larval shell subcircular, evenly arched and smooth, 350-400 $\mu \mathrm{m}$ wide (Fig. 2T). It is bounded by an elevated periphery from the post-larval shell. The brephic shell is gently transverse, $c a 1.5 \mathrm{~mm}$ broad, with transversally oval outline and evenly rounded periphery. Its surface is covered by weak growth fila more distinct around the periphery. Generally smoother surface distinguishes the brephic shell from the mature shell surface. Whole brephic shell with the larval shell attached to its posterior is gently inclined and posterodorsally faced.

The ornament of the dorsal valve consists of entire or imperfect concentric rugellae (Fig. 2N). New imperfect rugellae originate lateral to the apex, at about one-fourth of shell length. Some rugellae are short, and rapidly change into low, rope-like fila on surface of the interspace. Entire rugellae rapidly increase in size with shell growth, with new rugella always somewhat higher than the preceding one (Fig. 2L). Interspaces vary in width, having a flat bottom or bearing low, rope-like concentric fila. Rugellae are lamellose, resting almost perpendicularly to shell surface, with weakly thickened bases and gently thicken crests (Fig. 2H, K, L). Rugellae between the apex and the posterior margin are lower but the interspaces have coarser growth fila. Surface of interspaces and slopes of rugellae are covered by oblique lines (Fig. 2S, W). Microornament consists of densely crowded uniformly sized subcircular pits of $3 \mu \mathrm{m}$ diameter in regular honeycomb-like arrangement (Fig. 2Q).

Interior of the dorsal valve bears large, obliquely elongate and clearly impressed central muscle scars inclined $50^{\circ}$ each another and separated each another by a low median ridge (Fig. 2R). Visceral area is elongate rhomboidal in outline, $30 \%$ as wide as the valve and anteriorly extends to midvalve (Fig. 2O, P, R). Its posterior part is divided by a thin myophragm. Anterior and lateral margins bear distinct imprints of radially arranged terminal canals of the vascular system (Fig. 2R). Some of canals extend from gently divergent narrow canals of vascula media, which extend from anterior corners of central muscle scars. Small concave epithelian cell moulds cover the visceral field and adjacent parts of the interior (Fig. 2X). Ventral valve is unknown.

Remarks. - The fragments are similar to some Acrosaccus-like discinids with prominent concentric rugellae. However, lack of information about the ventral valve makes generic affiliation of Spanish specimens tentative. Several similar discinids of the Acrosaccus shape of the Lower Devonian age are known from the Barrandian area of the Czech Republic (Mergl 2001, 2008; Mergl \& Ferrová 2009; Mergl \& Jiménez 2015) but none of them has surface of interspaces and slopes of rugellae covered by oblique fila as exhibits the Acrosaccus sp. from Pyrenees. Likewise, none of fragmental ventral valves from our sample from Compte-I section show this distinct microornament. Among the European species, Acrosaccus sp. from the Suchomasty Limestone (Emsian) (Mergl \& Jiménez 2015) is most similar, but lacks the above mentioned oblique fila and its rugellae are much robust and much closely spaced. A similarly shaped

Figure 2. Acrosaccus sp. A; A, K - transverse dorsal valve exterior, dorsal and oblique views, sample CP-I/40A, specimen MGUV-36171; $\mathrm{B}$ - transverse dorsal valve exterior, dorsal and oblique views, sample CP-I/40A, specimen MGUV-36172; C, L, T - circular dorsal valve exterior, dorsal and oblique views, and detail of brephic shell in anterodorsal view, sample CP-IW/51top, specimen MGUV-36173; D - dorsal valve exterior, dorsal view, sample CP-I/40A, specimen MGUV-36174; E - dorsal valve exterior, dorsal view, sample CP-I/40A, specimen MGU-36175; F - elongate dorsal valve exterior, dorsal view, sample CP-I/40A, specimen MGUV-36176; G - dorsal valve exterior, dorsal view, sample CP-I/40A, specimen MGUV-36177; H - dorsal valve exterior, dorsal view, sample CP-I/40A, specimen MGUV-36178; I, M - dorsal valve exterior, oblique and dorsal views, sample CP-IW/52top, specimen MGUV-36179; J, Q - dorsal valve exterior, dorsal view and detail of microornament, sample CP-I/40A, specimen MGUV-36180; N - largest known dorsal valve exterior, dorsal view, sample CP-I/40e, specimen MGUV-36181; O, P, R, X - dorsal valve interior in anteroventral, ventral, and oblique views, and detail of visceral area showing epithelial cell moulds, sample CP-I/40B, specimen MGUV-36182; S, U-W - fragment of dorsal valve in various views showing shape of rugellae and oblique striation on shell surface (S), sample CP-I/40A, specimen MGUV-36183. Length of bars is $500 \mu \mathrm{m}(\mathrm{A}-\mathrm{P}), 200 \mu \mathrm{m}(\mathrm{R}, \mathrm{U}-\mathrm{W}), 100 \mu \mathrm{m}(\mathrm{S}, \mathrm{T})$, and $10 \mu \mathrm{m}(\mathrm{Q}, \mathrm{X})$. 


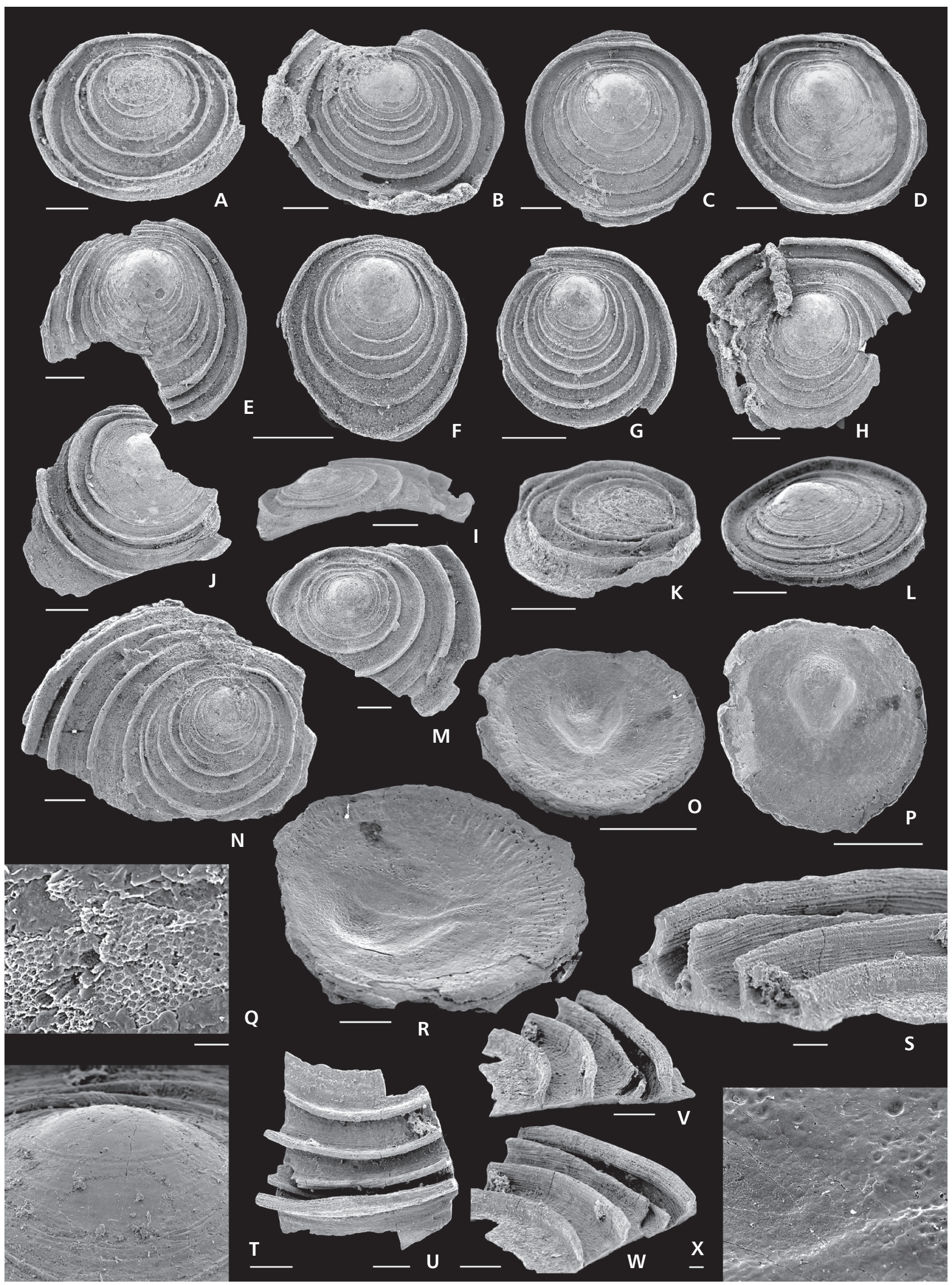


A. vertex Mergl \& Ferrová, 2009 was described from the Chýnice Limestone (upper Emsian), but the lamellose rugellae of Acrosaccus sp. are distinctly higher and more closely crowded. Acrosaccus sp. from the Acanthopyge Limestone (Eifelian) of the Barrandian area has similar lamellose rugellae in the dorsal valve, but its rugellae are lower than rugellae of $A$. sp. Similar species? Acrosaccus sp. has been described by Valentine (2006) from several limestone members of the Lower Devonian age of New South Wales, Australia, but none of illustrated specimens has as high rugellae as Acrosaccus sp. from Pyrenees. Unfortunately, the fine details is Australian shells are unknown.

The ventral valve of Acrosaccus sp. is unknown from our samples, while the dorsal valves are numerous (Tab. 1) and fairly well preserved. This disproportion may be explained by disintegration of thinner and much fragile ventral valve, likely having low conical shape. Similar disproportion in number of dorsal and ventral valves has frequently been observed in samples in the Barrandian area.

Similar variations of the shell outline observed in A. sp. are known in other Lower Palaeozoic discinoids (e.g. Orbiculoidea sp. C; Mergl 2001, pl. 17, figs 7, 8, 10-12). It is likely related to biotope of a particular specimen. It is worth a mention that the outline of brephic shell is constantly circular despite differently outlined postlarval shells. Pyrenean specimens surely belong to a new species but shortage of important piece of regarding the ventral valve led us to prefer an open taxonomic position.

Occurrence. - This species is the commonest lingulate brachiopod in samples of the Compte-I section (see Tab. 1 for details).

\section{Acrosaccus sp. B}

Figure 3A, D, E, I, J, V-X

Material. - Ten fragmentary ventral and dorsal valves, see table 1 (figured specimens MGUV-36184-36187).
Description. - Available shells are imperfect and therefore the species is poorly known. Fragments indicate that shell is thin-walled and subcircular to slightly elongate oval in outline. Dorsal valve has prominent, moderate convex subcircular brephic shell which is strongly tilted posterodorsally above a steep posterior slope of valve. Size of the brephic valve is around $500 \mu \mathrm{m}$. The mature shell bears fine thread-like concentric growth fila.

The ventral valve is low conical, with distinct brephic valve which slightly overhang the earliest part of the pedicle track. Pedicle track is narrowly triangular, with posteriorly moderate expanding listrial plates and narrow evenly broad inner listrial plate (Fig. 3A, D). Length of the pedicle track is about $1.5 \mathrm{~mm}$. It is posteriorly closed by mature shell bearing the same external ornament as adjacent posterolateral parts of the valve. The mature ventral valve is covered by concentric growth fila gradually increasing in a size toward shell periphery. The early lines encircling the apex are thread like and very fine, but fila from $2 \mathrm{~mm}$ sized shell are much higher, convex, with broad bases separated by unevenly sized interspaces.

Remarks. - Attribution of ventral valves (Fig. 3A, D, E) to dorsal valves (Fig. $3 \mathrm{~V}-\mathrm{X}$ ) is somewhat tentative, but it is based on similar type of ornament and biconvex shells profile similar to some species of the genus described elsewhere (Mergl 2001, 2006, 2008). Acrosaccus sp. A differs by distinct type of microornament and by coarse rugellae.

Occurrence. - This species is present in samples CP-I/34, CP-I/40A, CP-I/46B, CP-I/51B, CP-I/56, CP-IW/52C of the Compte-I section.

\section{Genus Chynithele Havlíček, 1996}

Type species. - Chynithele ventricona Havlíček in Havlíček \& Vaněk (1996); Zlíchov Formation, lower Emsian, Devonian; Prague Basin, Czech Republic.

Figure 3. A, D, E, I, J, V, W, X - Acrosaccus sp. B; A, I - incomplete ventral valve exterior, ventral and posterolateral views, sample CP-I/40e, specimen MGUV-36184; D, J - incomplete ventral valve exterior, ventral and posterolateral views, sample CP-I/40A, specimen MGUV-36185; $\mathrm{E}$ - incomplete ventral valve exterior, ventral view, sample CP-I/40A, specimen MGUV-36186; W - incomplete dorsal valve exterior, oblique view, sample CP-IW/52C, specimen MGUV-36187; V, X - incomplete dorsal valve exterior, oblique and dorsal views, sample CP-IW/52C, specimen MGUV-36188. • B, C, G - Schizotreta sp. B; B, C - incomplete dorsal valve exterior, dorsal and posterolateral views, sample CP-I/48, specimen MGUV-36189; G - incomplete dorsal valve exterior, dorsal view, sample CP-I/40A, specimen MGUV-36190. • F, H, K - ?Praeoehlertella sp.; incomplete dorsal valve exterior, dorsal and posterolateral views and detail of microornament (F), sample CP-I/34, specimen MGUV-36191. • L-S - Chynithele aff. fritschi (Barrande, 1879); L, O, Q - dorsal valve exterior, oblique and dorsal views, and detail of rugellate ornamentation, sample CP-IW/51 top, specimen MGUV-36192; M, N, P, R, S - dorsal valve exterior, oblique and dorsal views, details of microornament (P, S), and detail of rugellate ornamentation (R), sample CP-IW/51B, specimen MGUV-36193. • T - Barrandeoglossa sp.; fragment of dorsal valve, dorsal view, sample CP-I/34, specimen MGUV-36194; •U - Lochkothele cf. intermedia (Barrande, 1879), incomplete ventral valve exterior, ventral view, sample CP-I/30F, specimen MGUV-36195. •Y, Z - Schizotreta sp. A, dorsal valve exterior, oblique and dorsal views, sample CP-I/34, specimen MGUV-36196. Length of bars is $1 \mathrm{~mm}(\mathrm{~A}, \mathrm{~B}, \mathrm{~V}), 500 \mu \mathrm{m}$ (D, E, G, J, L-O, V-Z), $200 \mu \mathrm{m}(\mathrm{C}, \mathrm{H}, \mathrm{I}, \mathrm{K}, \mathrm{T}), 100 \mu \mathrm{m}(\mathrm{Q}, \mathrm{R}), 20 \mu \mathrm{m}(\mathrm{P}, \mathrm{S})$, and $10 \mu \mathrm{m}(\mathrm{F})$. 


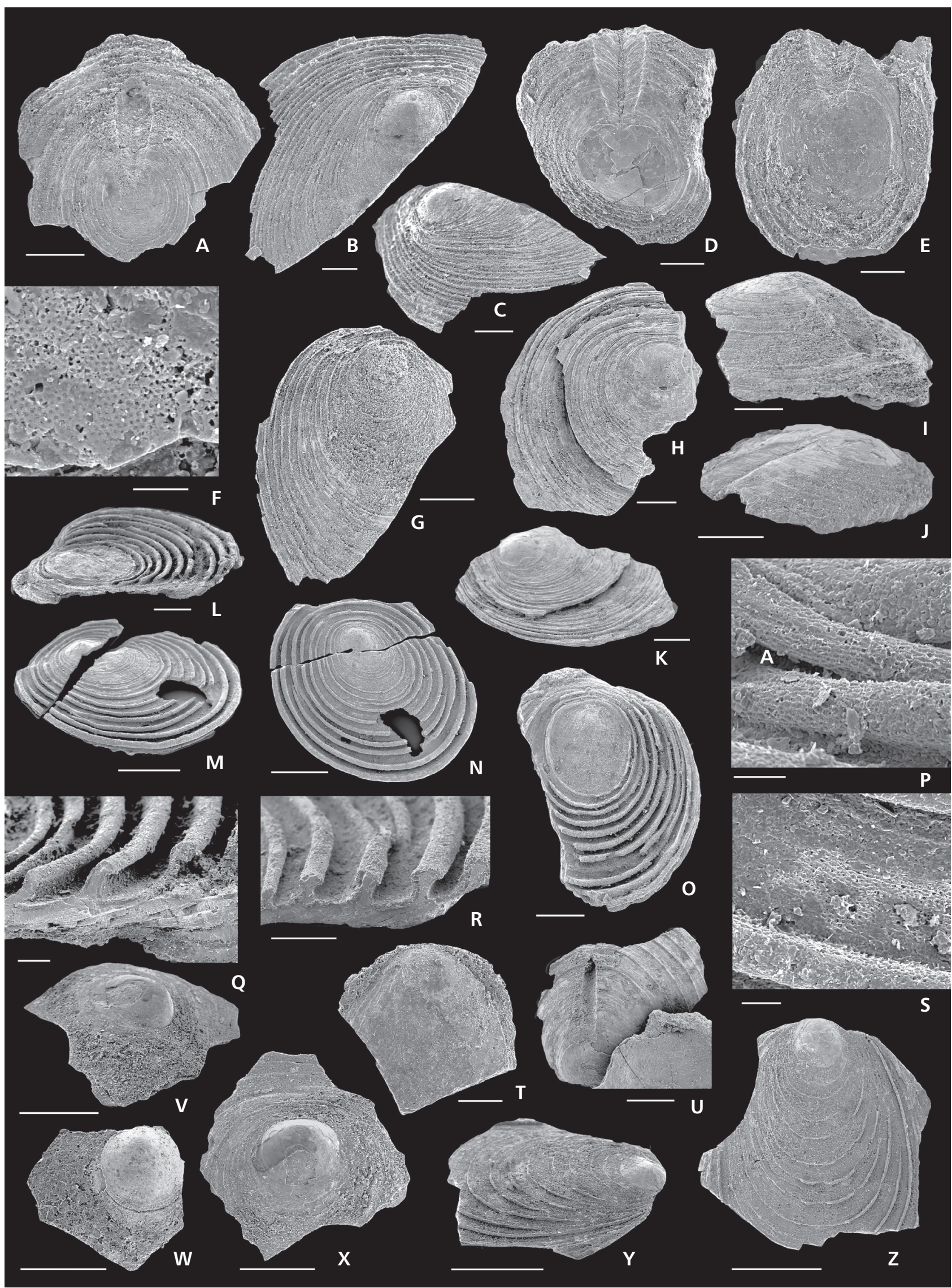


Chynithele aff. fritschi (Barrande, 1879)

Figure $3 \mathrm{~L}-\mathrm{S}$

Material. - Two dorsal valves, see Tab. 1 (MGUV-3619236193).

Description. - The dorsal valve is subcircular, ca $2 \mathrm{~mm}$ wide, gently concave, thick-walled, rectimarginate. The apex is situated at posterior one-fifth of the valve. The larval shell and brephic shell are not clearly differentiated. The brephic shell is weakly convex, about $280 \mu \mathrm{m}$ wide, encircled by very fine entire concentric rugellae of the early mature shell.

Ornamentation consists of mostly entire rugellae, with rare inserted imperfect rugellae which rapidly attain the same size of nearby entire rugellae. Sizes of rugellae progressively increase with shell growth (Fig. 3N, O). Rugellae are gently inclined forward. The crest of each rugella is broader than the base of rugella and form a short shelf that slightly overhang the anterior slope of the rugella (Fig. 3Q, R). Interspaces have flat or shallow concave bottom and are slightly wider than crests of adjacent rugellae. Microornament consists of small circular pits of $3 \mu \mathrm{m}$ diameter closely spaced. Pits covers entire surface of the mature shell (Fig. 3P, S).

Remarks. - Both specimens show distinct features of the genus: a weakly concave dorsal valve, generally entire, prominent and gradually larger rugellae with overhanging crests, and a microornament of fine circular pits. The genus Chynithele is represented by several successive species (C. fritschi - C. ventricona - C. intermedia - C. amoena) in the Barrandian area. These are known from the Emsian to Eifelian (Havlíček \& Vaněk 1996, Havlíček 1998, Mergl 2001, Mergl \& Ferrová 2009, Mergl \& Jiménez 2015). Apart from the stratigraphically earliest species, others species differs from the Spanish specimen by generally lower much robust rugellae and much transverse outline of dorsal valves. The species Chynithele fritschi (Barrande, 1879) from the lower Emsian (Zlíchov Formation) was erected on poorly preserved dorsal valve showing only internal characters. This species comes from the upper part of the Zlíchov Formation (lower Emsian) and its relationship to approximately coeval C. ventricona requires a detail revision. Undescribed species of Chynithele that differs from the Emsian and Eifelian species of the Barrandian area is also known from the Kotýs Limestone (Lochkovian) of the Barrandian (Mergl, unpublished data); this to date unnamed species has similar shaped concentric rugellae as the Spanish species.

Chynithele has been reported in the Lower Devonian of western New South Wales, Australia (Valentine 2006). The specimens labelled $C$. cf. ventricona Havlíček in Havlíček \& Vaněk, 1996 are similar to $C$. sp. by circular outline and microornament, but Valentine (2006) did not mention the profile of rugellae which is essential for to clarify the species relationship.

Occurrence. - Rare in samples CP-I/51B and CP-IW/ 51top of the Compte-I section.

\section{Genus Lochkothele Havlíček \& Mergl, 1988}

Type species. - Discina intermedia Barrande, 1879; Lochkov Formation, Lochkovian, Devonian; Prague Basin, Czech Republic.

\section{Lochkothele cf. intermedia (Barrande, 1879)}

Figure 3U

Material. - One fragment of ventral valve, see Tab. 1 (MGUV-39195).

Description. - The apical part of the ventral valve belongs, judging from growth lines, to subcircular, gently elongate thin walled shell. Larval shell is slightly transversely oval, about $500 \mu \mathrm{m}$ wide, with poorly defined border. The pedicle track is deeply incised, $0.8 \mathrm{~mm}$ long, evenly wide along its whole length (Fig. 3U). The track is posteriorly terminated by reversely V-shaped incision. The floor of the pedicle track is undifferentiated, evenly concave and covered by growth lines. Exterior of mature ventral valve is covered by growth fila accentuated in regular intervals into low rugellae. The first rugella appears $0.7 \mathrm{~mm}$ posteriorly from the apex and other rugellae are next arranged in regular distances $0.2 \mathrm{~mm}$ apart. Microornament is unknown in the specimen from Compte-I section.

Remarks. - The earliest Lochkothele is known from the Wenlock (Homerian). Several, usually rare occurrences of Lochkothele come from the Lochkovian (Havlíček \& Mergl 1988; Mergl 2001), the Emsian (Mergl 2001, Mergl \& Ferrová 2009, Mergl \& Jiménez 2015) and the Eifelian (Mergl \& Vodrážková 2012). All known species of the genus have distinct semitubular undifferentiated pedicle tracks, weakly ornamented ventral valves with closely packed concentric growth fila, and thin and low thread-like rugellae. The single available fragment may belong to Lochkothele intermedia (Barrande, 1879), the common species of Lochkovian age in the Barrandian area (Havlíček \& Mergl 1988).

Occurrence. - Only in the sample CP-I/40A of the Compte-I section.

\section{Genus Schizotreta Kutorga, 1848}

Type species. - Orbicula elliptica Kutorga, 1846; Volkhov or Kundan, Ordovician; northwestern Russia. 
Schizotreta sp. A

Figure $3 \mathrm{Y}, \mathrm{Z}$

Material. - One fragment of dorsal valve, see Tab. 1 (MGUV-36196).

Description. - Single available dorsal valve is elongateelliptical with the marginal apex and belongs to individual approximately $3 \mathrm{~mm}$ long judging from shaping of rugellae. The shell wall is moderately thin. The valve is weakly convex in transversely profile and gently depressed in the median sector. The larval shell is distinct, smooth, subcircular, $300 \mu \mathrm{m}$ wide, convex and gently inclined towards the posterior margin (Fig. 3Y). The postlarval shell is covered by rod-like concentric rugellae with new ones originating in a posterolateral sector by intercalation. Both concentric and new rugellae are uniformly sized, arranged in regular intervals $120-150 \mu \mathrm{m}$ apart along the axis of valve. Rugellae are gently inclined outwards, with anterior slope shortly undercut. Broad and flat floor of interspaces bears growth fila, which are distinct posterolaterally and suppressed anteromedially (Fig. 3Z).

Remarks. - The valve is similar to dorsal valves of Schizotreta vaneki Mergl \& Ferrová, 2009 from the Chýnice Limestone of the Barrandian area. However, this species is significantly younger (upper Emsian) and the ventral valve is unknown in the Compte-I locality. Moreover, the Spanish specimen differs by more elongate outline which has weak taxonomic significance and may be exaggerated by a tectonic deformation. Therefore we prefer an open taxonomical position.

Occurrence. - Rare in the sample CP-I/34 of the Compte-I section.

\section{Schizotreta sp. B}

Figure 3B, C, G

Material. - Thirty-one fragments of dorsal valves, see table 1 (figured specimens MGUV-36189-36190).

Description. - The dorsal valve is elongate oval, $2 \mathrm{~mm}$ wide, with maximum width at posterior one-third. Anterior margin is semicircular, sides are less rounded and the posterior margin is only gently curved, with nearly straight part posterior to the brephic valve (Fig. $3 \mathrm{~B}, \mathrm{G})$. The shell convexity is very low and decreases anteriorly. The apex is situated to one-fourth to onefifth of the valve, separated from the posterior margin by narrow band of steeply sloping shell bearing some rugellae (Fig. 3C). Larval and brephic shells are poorly known due preservation. The mature shell is covered by distinct but low, rope-like concentric rugellae, which are uniformly sized. Size of particular rugella gently changes with its location on valve; posterolateral part of rugella is higher and more distinct than its anteromedian partitions. Interspaces are broader than rugellae, with flat floor and surface covered by uneven growth fila.

Interior and ventral valve are unknown.

Remarks. - The valve differs from $S$. sp. A from the Pyrenees and from Schizotreta vaneki Mergl \& Ferrová, 2009 from the Chýnice Limestone (upper Emsian) of the Barrandian area by much densely crowded concentric rugellae.

Occurrence. - Rare in sample CP-I/34 of the Compte-I section.

\section{Genus Praeoehlertella Mergl, 2001}

Type species. - Praeoehlertella umbrosa Mergl, 2001; Praha Formation, Pragian, Devonian; Prague Basin, Czech Republic.

\section{Praeoehlertella sp.}

Figure 3F, H, K

Material. - One incomplete dorsal valve, see Tab. 1 (MGUV-36191).

Description. - The dorsal valve is poorly known, but from the development of growth lines may be deduced that shell is very broadly oval to almost circular, with evenly curved margins including the posterior margin. The apex is situated at posterior one-third, with low posterior slope bearing gently coarser ornament than developed on the rest of the valve (Fig. 3H, K). The brephic shell is about $300 \mu \mathrm{m}$ wide, gently vaulted, smooth and slightly tilted posterodorsally. The surface of post-larval shell bears densely crowded, low and broad concentric growth fila separated by narrow slit-like interspaces. One distinct largely extending growth lamella is present. Microornament consists of minute circular pits ( $\mathrm{ca} 1 \mu \mathrm{m}$ in diameter) densely covering entire surface excluding the brephic shell (Fig. 3F).

Remarks. - Our material is poor and therefore is referred to Praeohlertella Mergl, 2001 with uncertainty. Outline, convexity, location of the apex on the dorsal valve, and type of ornamentation are close to P. lukesi Mergl \& Jiménez, 2015 from the Suchomasty Limestone (upper Emsian) of the Barrandian area.

Occurrence. - Rare in sample CP-I/34 of the Compte-I section. 
Order Acrotretida Kuhn, 1949

Superfamily Acrotretoidea Schuchert, 1893

Family Biernatidae Holmer, 1989

\section{Genus Havlicekion Mergl, 2001}

Type species. - Havlicekion splendidus Mergl, 2001; Praha Formation, Pragian, Devonian; Prague Basin, Czech Republic.

\section{Havlicekion cf. holynensis Mergl, 2001}

Figure 4

Material. -44 dorsal and 11 ventral valves, see Tab. 1 (figured specimens MGUV-36197-36207).

Description. - The shell is fairly large for the genus with the ventral valve $1.5 \mathrm{~mm}$ tall having a broadly unisulcate commissure (Fig. 4Q). The dorsal valve is subcircular, with evenly rounded posterior margin and weak and broad sulcus. Larval shell has two distinct nodes (Fig. 4F). The larval shell is $200 \mu \mathrm{m}$ wide, slightly overhanging the posterior edge of post-larval shell. Dorsal pseudointerarea is anacline, with straight anterior edge and very shallow widely triangular median groove. Median septum is high, thin, having steeply sloping anterior edge towards a weakly defined marginal brim. It occupies $80 \%$ of valve length. The surmounting plate is inclined at about $45^{\circ}$ toward shell floor, the lower rod is at about $35^{\circ}$ (Fig. 4P, Q). The surmounting plate anterior tip is at the midvalve, the tip of the lower rod at two-third of the valve. The crest of surmounting plate is rounded, slightly flattened near its anterior end. The end is blunt. The proximal part of the lower rod is less distinct, but its distal part is distinct but less robust than the surmounting plate. Anterior end of the lower rod deviates to right or left side from the plane of symmetry. Cardinal muscle scars are large, elongate oval, $30 \%$ as long as the valve (Fig. $4 \mathrm{~L}, \mathrm{O}$ ).

The ventral valve is tall cone, with clearly flattened and fairly broad catacline ventral pseudointerarea. The larval shell is asymmetrically conical with slightly extended part near the foramen (Fig. 4S). The larval shell is pierced by large circular ventrally directed foramen just above steep posterior slope. Lateral and anterior slopes of the valve are gently convex in lateral profile having gradually changing slope from moderate near beak to steeper in later growth stages.

Ornament of the dorsal valve consists of low concentric rugellae of uniform size separated by narrow interspaces. The concentric ornament is more distinct on dorsal valve. The ventral valve is weakly rugellate having rugellae crossed by radial striae (Fig. $4 \mathrm{~W}$ ). The width of rugellae is 8 to $10 \mu \mathrm{m}$. This combination forms a draperylike relief, which obscure the rugellate ornament. Larval shell is covered by uniformly sized flat-bottomed circular pits of $5 \mu \mathrm{m}$ diameter. Pits are regularly arranged, closely spaced and only rarely intersecting (Fig. 4T-V).

Remarks. - The specimens are very similar to Havlicekion holynensis Mergl, 2001 from the Kotýs Limestone of the Lochkovian age of the Barrandian area. There is only one difference on dorsal median septum. Distance between the surmounting plate and lower rod is smaller in H. holynensis and a blade-like part of septum between them is distinctly shorter than those in $H$. cf. holynensis from Spain. The surmounting plate on $H$. holynensis may be weakly concave in lateral profile and is triangular in a cross-section (Mergl 2001, pl. 34, fig. 9) but this is straight and rod-like in $H$. cf. holynensis. Current knowledge of phenotypic plasticity of the shell interior of biernatiids is not satisfactory for evaluation of the taxonomical value of these minor differences. Therefore we are aware using observed minor differences between specimens for definition of separate species.

Occurrence. - Abundant in 13 samples of the Compte-I section (see Tab. 1 for details).

\section{Discussion}

Our current state of knowledge of the Silurian and Devonian organophosphatic micromorphic brachiopods extracted from carbonates is rather weak. Many issues of their palaeogeography, palaeoecology, evolutionary history and some aspects of their shell morphology remain to be solved. This deficiency contrasts with extent of

Figure 4. Havlicekion cf. holynensis Mergl, 2001; A-C, S, U, W - ventral valve exterior, oblique, lateral and anteroventral views, side view to larval shell (S), contact between larval and mature shell (U) and ornament of mature shell (W), sample CP-IW/52C, specimen MGUV-36197; D - ventral valve with broken wall, posterolateral view, CP-IW/52C, specimen MGUV-36198; E, H, T, V - ventral valve exterior, posterior view, detail of larval shell in posterior and lateral views, and pitted ornamentation of the larval shell, sample CP-IW/52C, specimen MGUV-36199; F - dorsal valve exterior, dorsal view, sample CP-I/12, specimen MGUV-36200; G, J - dorsal valve exterior, dorsal and oblique views, sample CP-I/40A, specimen MGUV-36201; I - ventral valve exterior showing larval shell and ornamentation of ventral pseudointerarea, sample CP-I/12, specimen MGUV-36201; K - dorsal valve exterior, dorsal view, sample CP-I/12, specimen MGUV-36202; L - dorsal valve interior, ventral view, sample CP-IW/52C, specimen MGUV-36203; $\mathrm{M}$ - dorsal valve interior, ventral view, sample CP-IW/52C, specimen MGUV-36204; N - dorsal valve interior, ventral view, sample CP-I/12, specimen MGUV-36205; O-Q - dorsal valve interior, ventral, side and oblique views, sample CP-I/40A, specimen MGUV-36206; 18 - dorsal valve interior, side view, sample CP-IW/52C, specimen MGUV-36207. Length of bars is $200 \mu \mathrm{m}(\mathrm{A}-\mathrm{G}, \mathrm{J}-\mathrm{R}), 100 \mu \mathrm{m}$ (I), $50 \mu \mathrm{m}(\mathrm{H}, \mathrm{S}, \mathrm{T}, \mathrm{W})$, and $20 \mu \mathrm{m}$ (U, V). 


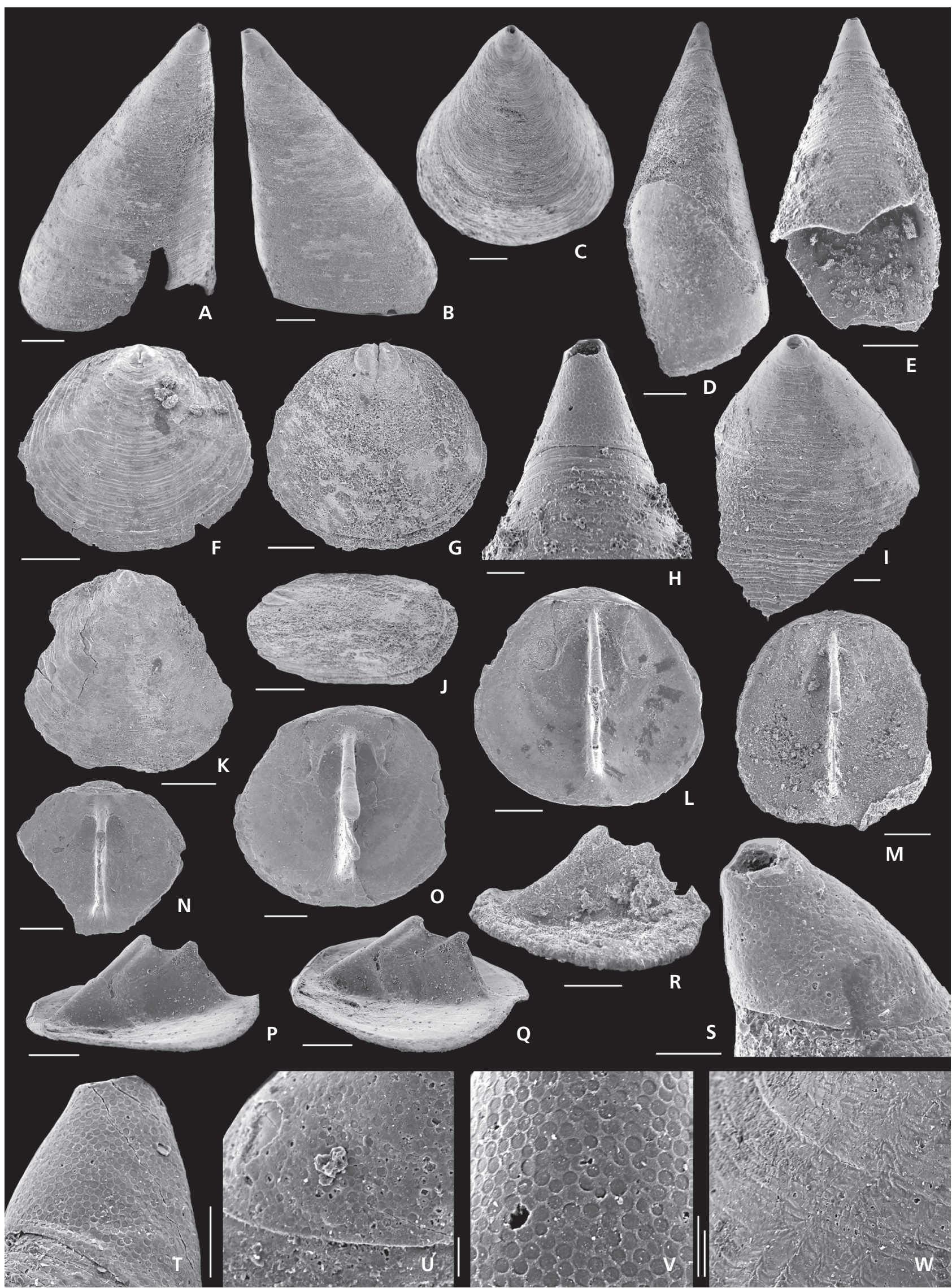


information about morphology and evolutionary history of the group based on samples from early Cambrian to latest Ordovician; mostly extensive or summarizing works have been published in last decades (Biernat 1973; Holmer 1989; Popov \& Holmer 1994; Bassett et al. 1999, 2002; Sutton et al. 1999, 2000; Holmer et al. 2001; Mergl 2002; Robson \& Pratt 2007, and others).

This difference is not caused by sampling methods, because organophosphatic microbrachiopods can be easily extracted by weak acid solution from limestone of any age. However, unlike Cambrian and Ordovician rocks, abundance, diversity and disparity of organophosphatic microbrachiopods are markedly lower in the Silurian and Devonian carbonates. Therefore, due to their rarity and unattractiveness, few works are focused on Devonian microbrachiopods. To date, the reliable data referred to them came from two distant areas: New South Wales, Australia (Brock et al. 1995, Valentine 2006) and the Barrandian area of the Czech Republic (Mergl 2001, 2008, 2019; Mergl \& Ferrová 2009; Mergl \& Vodrážková 2012; Mergl \& Jiménez 2015). Scattered data about ubiquitous biernatid Opsiconidion also came from other areas with Devonian rocks (Arctic Canada, Ludvigsen 1974; Novaya Zemlja, Popov 1981; Mongolia, Arno 2010; Podolia, Ukraine, Baliński 2012; Carnic Alps, Suttner \& Kido 2016). Research on these Devonian microbrachiopods has often been focused on shell morphology and ultrastructure of larval shell (Williams \& Hurst 1977, Von Bitter \& Ludvigsen 1979, Williams 2003).

Regarding current knowledge of Devonian microbrachiopods, the new Pyrenean record of microbrachiopods from lower Lochkovian to early Pragian represent important contribution to elucidate the Lower Devonian microbrachiopod history. Three taxa ascribed as Acrosaccus sp. A, Schizotreta sp. B and Havlicekion cf. holynensis range across the Lochkovian and reach the stratigraphic level very close to the Lochkovian-Pragian boundary (Fig. 1C). Barrandeoglossa sp., Schizotreta sp. A, ?Praeoehlertella sp., and Lochkothele cf. intermedia are restricted to middle Lochkovian in the section CP-I, and only Acrosaccus sp. B crosses the Lochkovian-Pragian boundary. The Pyrenean records of Chynithele aff. fritschi begin close to the base of the Pragian in CP-I section. Although fragmentation and rarity of shells hamper accurate taxonomic evaluation, a general composition of lingulate fauna indicates uniformity of microbrachiopods in Early to Middle Devonian tropical marine fauna.

The microbrachiopod assemblage from Spanish Central Pyrenees is similar to ones known from the Lochkovian and the Pragian of the Barrandian area, the Czech Republic. Dominance of small discinoids, a glossellid Barrandeoglossa and a biernatiid Havlicekion cf. holynensis indicates a moderately shallow envi- ronment, similar to depositional environment of the Kotýs Limestone (Lochkov Formation, Lochkov) in the Barrandian area (Chlupáč 1998). This agrees with previous palaeoenvironmental interpretations (ValenzuelaRíos \& Liao 2012, Slavík et al. 2016, Valenzuela-Ríos et al. 2017). Absence of a lingulate Paterula and presumable absence of biernatiid Opsiconidion (although cannot be excluded, that small fragments of biernatiids from Pyrenees belong to this genus) indicate a limited influx of deeper and/or hypoxic environment in Pyrenees (see Mergl 1999, Mergl \& Vodrážková 2012 for discussion). Large thick-shelled lingulates are totally absent in our samples from Pyrenees. In general, the Spanish Pyrenees assemblage is remarkably similar to the ones from Lower Devonian, Barrandian area and to ones reported from New South Wales, Australia (Brock et al. 1995, Valentine 2006). The Spanish Pyrenean fauna likely represents one of so far rare examples of the "standard" microbrachiopod association of shallow to moderately deep environment of Lower Devonian tropical climatic zone.

All three Devonian occurrences of microbrachiopods (New South Wales, Central Bohemia, and newly the Spanish Pyrenees) are typical by dominance of very small sized ("dwarf”) shells. All areas were located within tropical climatic zone with intensive carbonate production on reefs and carbonate platforms in the Early Devonian (Fig. 5). Small size of organophosphatic brachiopods in these areas greatly contrasts with many times larger shells of organophosphatic brachiopods populated siliciclastic shelves, mostly but not exclusively present in highlatitude sites during the Early Devonian. More or less well known medium- to large-sized discinoids are known from Argentina (Kayser 1897, Mendez-Alzola \& Sprechmann 1971), Bolivia (Knod 1908), Uruguay (Figueiras 1991), Paraguay and Brazil (Clarke 1913, Boucot et al. 2001), Antarctica (Rowell in Doumani et al. 1965), Falkland Islands (Morris \& Sharpe 1846, Rowell in Doumani et al. 1965, Mergl \& Massa 2005), South Africa (Reed 1925), and Libya and Algeria (Mergl \& Massa 2005) (for more references see Lech 2011). Similarly large discinoids are known from siliciclastics of the Rhenish Massif, Germany (Kayser 1892) and New York, U.S.A. (Vanuxem 1842). Some represents the largest organophosphatic brachiopods so far known with shell size exceeding $60 \mathrm{~mm}$ width (Mergl \& Massa 2005). Indeed, their shell size indicates that phosphorus was easily accessible in surrounding water.

Small size of organophosphatic brachiopods from limestone was likely consequence of nutrient scarcity, especially phosphate depleted waters at ancient reefs. On the Recent reef complexes nutrient-poor (oligotrophic) waters dominate (Sheppard et al. 2018). That is in striking contrast with enormous biotic diversity at the Recent reefs. The similar circumstances could be suggested for 


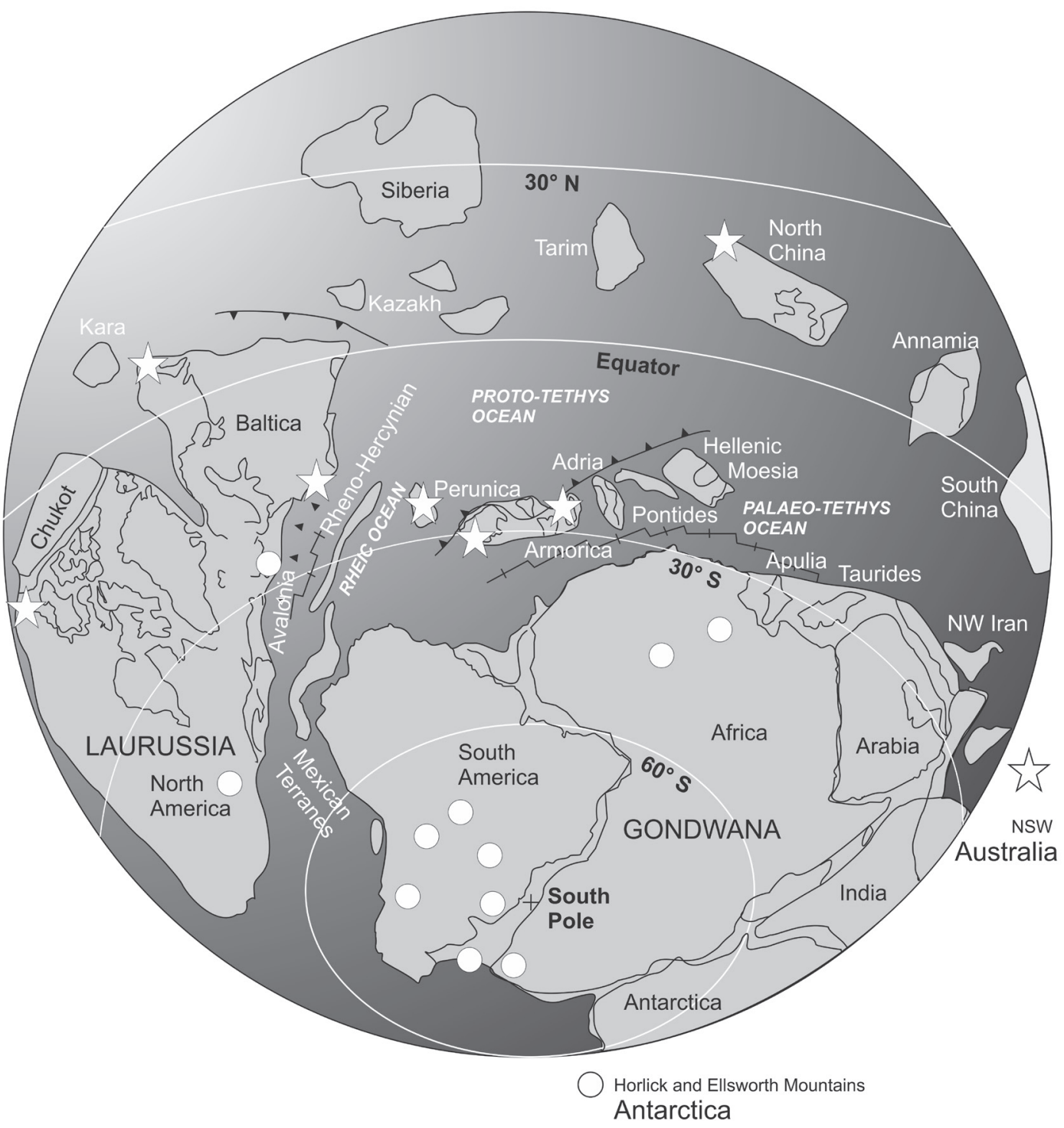

Figure 5. Palaeogeographic reconstruction for the Early to Middle Devonian time showing geographical distribution of biernatiids (asterisk) and large discinoids (circles) (for references see text). The sites on the reverse Earth hemisphere are marked outside map. Modified from Cocks \& Torsvik (2006).

the Devonian reefs. The dissolved inorganic phosphorus in form of phosphate $\left(\mathrm{PO}_{4}\right)^{3-}$ is particularly important for reef organisms in the Recent reefs. Reef waters have about only $20 \%$ concentration of phosphate in comparison with concentration of dissolved phosphate in deep waters. In areas with upwelling waters the input of phosphate may be significantly higher. Run-off of nutrient rich water from land is another significant input of phosphate into nearby sea (Sheppard et al. 2018).

Run-off of phosphate from land to shallow siliciclastic shelves was likely the significant trigger for production of large shelled organophosphatic brachiopods in the Devonian. This could be the case of large-sized discinoid populations on high latitude cratonic basins on Gondwana (Malvinokaffric Realm) or low latitude shelves with significant input of siliciclastics (Rhenish Massif, New York) (Fig. 5). The Recent large discinoid brachiopods occurs in shallow littoral zone near upwelling sites (west coast of Africa and west coast of South America; Hiller 1993, Mergl 2010, Zezina 2010) while their tropical allies are small sized, rare and often occupying a cryptic habitat (Paine 1962; Kato 1996; Zezina 2008, 2010). Similarly, the analogous depletion of phosphate in waters in the Devonian reef contributed miniaturization and retreat of organophosphatic brachiopods from this environment in mid-Palaeozoic. 


\section{Conclusion}

The microbrachiopod assemblage from Spanish Central Pyrenees is similar to ones known from the Lochkovian and the Pragian of the Barrandian area, the Czech Republic. Hence the Spanish Pyrenean fauna likely represents one of so far rare examples of the "standard" microbrachiopod association of shallow to moderately deep environment of Lower Devonian tropical climatic zone. Small size of organophosphatic brachiopods from limestone was likely consequence of nutrient scarcity, especially phosphate depleted waters around the ancient reefs. This also contributed to retreat of organophosphatic brachiopods from this environment during the mid-Palaeozoic.

\section{Acknowledgements}

We thank Lars Holmer and an anonymous reviewer for comments that greatly enhanced this work. We thank Jana Nebesářová, Jiří Vaněček, and Tomáš Bílý (Biology Centre of Czech Academy of Science, České Budějovice) for help with SEM work, and JauChyn Liao (Department of Botany and Geology, University of Valencia) for the draft of Figure 1. Sampling campaigns in the Pyrenees were partly supported by the Alexander von HumboldtStiftung and by the National Grant CGL 2011-24775 (Spain) and by funding provided by the University of West Bohemia at Plzeň (Czech Republic). It represents a contribution to the IGCP-652 project.

\section{References}

Arno, Z. 2010. Givetian (Middle Devonian) Opsiconidion (Phylum Brachiopoda, Class Inarticulata, Order Acrotretida) from the Gobialtai Formation, Shine Jinst Region, Southern Mongolia. Geological Society of America, Abstracts with Programs 42(1), 65.

BALIŃski, A. 2012. The brachiopod succession through the Silurian-Devonian boundary beds at Dnistrove, Podolia, Ukraine. Acta Palaeontologica Polonica 57(4), 897-924. DOI 10.4202/app.2011.0138

Barrande, J. 1879. Systême silurien du centre de la Bohême. Iére partie. Recherches paléontologiques. Vol. 5. Classe des Mollusques. Ordre des Brachiopodes. 226 pp. Privately published, Prague \& Paris.

Bassett, M.G., Popov, L.E. \& Holmer, L.E. 1999. Organophosphatic brachiopods: patterns of biodiversification and extinction in the early Palaeozoic. Géobios 32, 145-163. DOI 10.1016/S0016-6995(99)80026-6

Bassett, M.G., Popov, L.E. \& Holmer, L.E. 2002. Brachiopods: Cambrian-Tremadoc precursors to Ordovician radiation events, 13-23. In Crame, J.A. \& Owen, A.W. (eds) Palaeobiogeography and Biodiversity Change: the Ordovician and Mesozoic-Cenozoic Radiations. Geological Society London, Special Publication 194. DOI 10.1144/GSL.SP.2002.194.01.02
Biernat, G. 1973. Ordovician inarticulate brachiopods from Poland and Estonia. Palaeontologia Polonica 28, 1-120.

Boucot, A.J., Rowell, A.J., Racheboeuf, P., Pereira, E., Gonçalves de Melo, J.H. \& Peixoto de Siqueira, L. 2001. Position of the Malvinokaffric Realm's northern boundary (Early Devonian) based on newly discovered brachiopods from the Parecis Basin (Brazil). Journal of the Czech Geological Society 46, 109-120.

Brock, G.A., Engelbretsen, M.J. \& Dean-Jones, G. 1995. Acrotretoid brachiopods from the Devonian of Victoria and New South Wales. Memoir of Association of Australasian Palaeontologists 18, 105-120.

Chlupáč, I. 1998. Devonian, 101-133. In Chlupáč, I., HavlíČEK, V., Kř́iž, J., KuKal, Z. \& ŠTorch, P. Palaeozoic of the Barrandian (Cambrian to Devonian). Czech Geological Survey, Prague.

Clarke, J.M. 1913. Fósseis Devonianos do Paraná. Monographias do Servico Geológico e Mineralógico do Brasil 1, 1-353. DOI 10.5962/bhl.title.146614

Cocks, L.R.M. \& Torsvik, T.H. 2006. European geography in a global context from the Vendian to the end of Palaeozoic, 83-95. In Gee, D.G. \& Stephenson, R.A. (eds) European Lithopshere dynamics. Geological Society London, Memoir 32. DOI 10.1144/GSL.MEM.2006.032.01.05

Cooper, G.A. 1956. Chazyan and related brachiopods. Smithsonian Miscellaneous Collection 127, 1-1245.

Dojen, C., Valenzuela-Ríos, J.I. \& Carls, P. 2009. Ostracodes of Spain (Pyrenees, Celtiberia) and Early Devonian biostratigraphy. Palaeontographica Americana 63, 145-155.

Doumani, G.A., Boardman, R.S., Rowell, A.J., Boucot, A.J., Johnson, J.G., McAlester A.L., SAul, J., Fisher, D.W. \& Miles, R.S. 1965. Lower Devonian Fauna of the Horlick Formation, Ohio Range, Antarctica, 241-274. In HADlEY, J.B. (ed.) Geology and Paleontology of the Antarctic, Volume 6. American Geophysican Union. Garamond/Pridemark Press, Inc. Baltimore. DOI 10.1029/AR006p0241

Figueiras, A. 1991. Fauna eodevonica del Uruguay. Revista Technica de YPFB 12(1), 57-64.

Gray, J.E. 1840. Synopsis of the contents of the British Museum, $42^{\text {th }}$ edition. 370 pp. British Museum, London.

HAvlíčEK, V. 1998. Review of brachiopods in the Chapel Coral Horizon (Zlíchov Formation, lower Emsian, Lower Devonian, Prague Basin). Věstnik Českého geologického ústavu 73(2), 113-132.

Havlíček, V. \& Mergl, M. 1988. Two new discinid genera (Brachiopoda) from the Silurian and Devonian of the Prague Basin, Czechoslovakia. Věstnik Českého geologického ústavu 63, 169-172.

HAVLÍČEK, V. \& VANĚK, J. 1996. Brachiopods and trilobites in the Chýnice Limestone (Emsian) at Bubovice (Čeřinka hillside; Prague Basin). Palaeontologica Bohemiae 2, 1-16.

HiLler, N. 1993. A modern analogue for the Lower Ordovician Obolus conglomerate of Estonia. Geological Magazine 130(2), 365-367. DOI 10.1017/S0016756800009912

Holmer, L.E. 1989. Middle Ordovician phosphatic inarticulate brachiopods from Västergötland and Dalarna, Sweden. Fossils and Strata 26, 1-172. 
Holmer, L.E., Popov, L.E., Koneva, S.P. \& Bassett, M.G. 2001. Cambrian - early Ordovician brachiopods from Malyi Karatau, the western Balkhash region, and Tien Shan, Central Asia. Special papers in Palaeontology 65, 1-180.

Kato, M. 1996. The unique intertidal subterranean habitat and filtering system of a limpet-like brachiopod, Discinisca sparselineata. Canadian Journal of Zoology 74(11), 1983-1988. DOI 10.1139/z96-225

KAYser, E. 1892. Beitrage zur Kenntnis der Fauna der Siegenischen Grauwacke. Jahrbuch der köninglichen preussischen geologischen Landesanstalt 2(8), 95-107.

KAYSER, E. 1897 Beiträge zur Kenntnis einiger paläozoischer Faunen Süd-Americas. Zeitschrift der Deutschen Geologischen Gesellschaft 49, 274-317.

KING, W. 1846. Remarks on certain genera belonging to the class Palliobranchiata. Annals and Magazine of Natural History (series 1) 18, 26-42.

DOI 10.1080/037454809494387

KnoD, R. 1908. Devonische Faunen Boliviens. 493-600. In Steinmann, G. Beiträge z Geologie und Paläontologie Südamericas. Neues Jahrbuch für Mineralogie, Geologie und Paläontologie 25.

Kunn, O. 1949. Lehrbuch der Paläozoologie. 326 pp. Schweizerbart, Stuttgart.

Kutorga, S.S. 1846. Ueber das silurische und devonische Schichten-System von Gatschina. Russisch-Kaiserliche Mineralogische Gesellschaft zu St. Petersbourg, Verhandlungen 1845-46, 85-139.

Kutorga, S.S. 1848. Ueber die Brachiopoden-familie der Siphonotretaceae. Russisch-Kaiserliche Mineralogische Gesellschaft zu St. Petersbourg, Verhandlungen 1847, 250-286.

LECH, R.R. 2011. A review of Orbiculoidea saltensis Reed, Brachiopoda: Discinidae, of Upper Carboniferous of Argentina. Serie Correlación Geológica 27(1), 07-16.

Ludvigsen, R. 1974. A new Devonian acrotretid (Brachiopoda, Inarticulata) with unique protegular ultrastructure. Neues Jahrbuch für Geologie und Paläontologie, Monatshefte 1974(3), 133-148.

Mendez-Alzola, R. \& Sprechmann, P. 1971. Algunas orbiculoideas devonicas de la Precordillera de San Juan, Rep. Argentina. Revista de la Asociació Geológica Argentina 24(4), 517-525.

Menke, C.T. 1828. Synopsis methodica molluscorum generum omnium et specierum earum quae in Museo Menkeano adservantur. 169 pp. G. Uslar, Pyrmonti.

DOI 10.5962/bhl.title.13182

Mergl, M. 1999. Genus Paterula (Brachiopoda) in Ordovician-Silurian sequence of Central Bohemia. Věstnik Českého geologického ústavu 74(3), 347-361.

Mergl, M. 2001. Lingulate brachiopods of the Silurian and Devonian of the Barrandian. Acta Musei Nationalis Pragae, Series B-Historia Naturalis 57, 1-49.

Mergl, M. 2002. Linguliformean and craniiformean brachiopods of the Ordovician (Třenice to Dobrotivá Formations) of the Barrandian, Bohemia. Acta Musei Nationalis Pragae, series BHistoria Naturalis 58(1-2), 1-82.
Mergl, M. 2006. A review of Silurian discinoid brachiopods from historical British localities. Bulletin of Geosciences 81(4), 215-236. DOI 10.3140/bull.geosci.2006.04.215

Mergl, M. 2008. Lingulate brachiopods from the Acanthopyge Limestone (Eifelian) of the Barrandian, Czech, Republic. Bulletin of Geosciences 83(3), 281-298.

DOI 10.3140/bull.geosci.2008.03.281

Mergl, M. 2010. Discinoid brachiopod life assemblages: Fossil and extant. Bulletin of Geosciences 85(1), 27-38.

DOI 10.3140/bull.geosci.1161

Mergl, M. 2019. Lingulate brachiopods across the Kačák Event and Eifelian-Givetian boundary in the Barrandian area, Czech Republic. Bulletin of Geosciences 94(2), 169-186. DOI 10.3140/bull.geosci. 1740

Mergl, M. \& Ferrová, L. 2009. Lingulate brachiopods from the Chýnice Limestone (upper Emsian, Barrandian; Czech Republic). Bulletin of Geoscinces 84(3), 525-546. DOI 10.3140/bull.geosci.1143

Mergl, M. \& JimÉNEZ, A. 2015. Lingulate brachiopods from the Suchomasty Limestone (upper Emsian) of the Barrandian, Czech Republic. Bulletin of Geosciences 90(1), 173-193. DOI 10.3140/bull.geosci.1533

Mergl, M. \& Massa, D. 2005. A new giant discinoid brachiopod from the Lower Devonian of Algeria. Acta Palaeontologica Polonica 50(2), 397-402.

Mergl, M. \& VodrÁžKovÁ, S. 2012. Emsian-Eifelian lingulate brachiopods from the Daleje-Třebotov Formation (Třebotov and Suchomasty limestones) and the Choteč Formation (Choteč and Acanthopyge limestones from the Prague Basin; the Czech Republic. Bulletin of Geosciences 87(2), 315-332. DOI 10.3140/bull.geosci.1298

Morris, J. \& Sharpe, D. 1846. Description of Eight Species of Brachiopod Shells from the Paleozoic Rocks of the Falkland Islands. Quarterly Journal Geological Society London 2, 274-278. DOI 10.1144/GSL.JGS.1846.002.01-02.47

Murphy, M.A. \& Valenzuela-Ríos, J.I. 1999. Lanea new genus, lineage of Early Devonian conodonts. Bolletino della Società Paleontologica Italiana 37(2-3), 321-334.

PAINE, R.T. 1962. Filter-feeding pattern and local distribution of the brachiopod Discinisca strigata. Biological Bulletin 123(3), 597-604. DOI 10.2307/1539581

Popov, L.E. 1981. Pervaya nachodka bezzamkovich brachiopod semejstva Acrotretidae v nizhnem devone SSSR, 61-65. In Bondarev, V.I. (ed.) Paleontologitsheskaya osnova stratigrafitscheskikh schem paleozoya i mezozoya ostrovov Sovetskoy Arktiki. Nautschno Issledovatelskiy Institut geologii Arktiki, Leningrad.

Popov, L.E. \& Holmer, L. 1994. Cambrian-Ordovician lingulate brachiopods from Scandinavia, Kazakhstan, and South Ural Mountains. Fossils and Strata 35, 1-156.

ReEd, F.R.C. 1925. Revision of the Fauna of the Bokkeveld Beds. Annals of the South African Museum 22, 27-225. DOI 10.1111/j.1502-3931.1994.tb01571.x

Robson, S.P. \& Pratt, B.R. 2007. Late Marjuman (Cambrian) linguliformean brachiopods from the Deadwood Formation of South Dakota. Palaeontographica Canadiana 27, 1-95. DOI 10.1111/j.1502-3931.2006.00003.x 
Schuchert, C. 1893. Classification of the Brachiopoda. American Geologist 11, 141-167.

Sheppard, C.R.C., Davy, S.K., Pilling, G.M. \& Graham, N.A.J. 2018. The Biology of Coral Reefs. 370 pp. Oxford University Press, New York. DOI 10.1093/oso/9780198787341.001.0001

Slavík, L., Valenzuela-Ríos, J.I., Hladil, J. \& Carls, P. 2007. Early Pragian conodont-based correlations between the Barrandian area and the Spanish Central Pyrenees. Geological Journal 42, 499-512. DOI 10.1002/gj.1087

Slaví, L., Valenzuela-Ríos, J.I., Hladil, J., Chadimová, L., Liao, J-C., HušKová, A., Calvo, H. \& Hrstka, T. 2016. Warming or cooling in the Pragian? Sedimentary record and petrophysical logs across the Lochkovian-Pragian boundary in the Spanish Central Pyrenees. Palaeogeography, Palaeoclimatology, Palaeoecology 449, 300-320.

DOI 10.1016/j.palaeo.2016.02.018

SutTNER, T.J. \& KIDO, E. 2016. Distinct sea-level fluctuations and deposition of a megaclast horizon in the neritic Rauchkofel Limestone (Wolayer area, Carnic Alps) correlate with the Lochkov-Prag Event, 11-23. In Becker, R.T., Königshof, P. \& BRETt, C.E. (eds) Devonian climate, sea level and evolutionary events. Geological Society London, Special Publication 423. DOI 10.1144/SP423.1

Sutton, M.D., Bassett, M.G. \& Cherns, L. 1999. Lingulate brachiopods from the Lower Ordovician of the Anglo-Welsh Basin. Part 1. Monograph of the Palaeontographical Society London 610, 1-60.

Sutton, M.D., Bassett, M.G. \& Cherns, L. 2000. Lingulate brachiopods from the Lower Ordovician of the Anglo-Welsh Basin. Part 2. Monograph of the Palaeontographical Society London 613, 61-114.

Valentine, J.L. 2006. Early Devonian brachiopods from the Cobar Supergroup, western New South Wales, 192-259. In VALEntine, J.L. Taxonomic assessemnt, biostratigraphy and faunal turnover of Silurian-early Devonian linguliformean brachiopods from New South Wales, Australia. Ph.D. thesis. Macquarie University, Sydney.

Valenzuela-Ríos, J.I. 1990. Lochkovian Conodonts and Stratigraphy at Gerri de la Sal (Pyrenees). Courier Forschungsinstitute Senckenberg 118, 53-63.

Valenzuela-Ríos, J.I. 1994a. Conodontos Lochkoviense y Praguiense (Devónico Inferior) del Pirineo Central Español. Memorias del Museo Paleontológico de la Universidad de Zaragoza 5, 1-142.

Valenzuela-Ríos, J.I. 1994b. The Lower Devonian conodont Pedavis pesavis and the pesavis Zone. Lethaia 27(3), 199-207. DOI 10.1111/j.1502-3931.1994.tb01409.x

VALENZUELA-Ríos, J.I. 2002. Lochkovian and Pragian Conodonts from Segre 1 (Central Spanish Pyrenees), 403-418. In García-López, S. \& Bastida, F. (eds) Palaeozoic conodonts from Northern Spain. Cuadernos del Museo Geominero 1. Instituto Geológico y Minero de España.

Valenzuela-Ríos, J.I. \& LiaO, J.-C. 2012. Color/facies changes and Global Events, a hoax? A case study from the Lochkovian
(Lower Devonian) in the Spanish Central Pyrenees. Palaeogeography, Palaeoclimatology, Palaeoecology 367-368, 219-230. DOI 10.1016/j.palaeo.2011.09.007

Valenzuela-Ríos, J.I. \& Murphy, M.A. 1997. A new zonation of middle Lochkovian (Lower Devonian) conodonts and evolution of Flajsella n. gen. (Conodonta), 131-144. In Klapper, G., Murphy, M.A \& Talent, J.A. (eds) Paleozoic Sequence Stratigraphy and Biogeography: Studies in Honor of J. Granville ("Jess") Johnson. Geological Society of America, Special Paper 321. DOI 10.1130/0-8137-2321-3.131

Valenzuela-Ríos, J.I., Liao, J.-C. \& Martínez-Pérez, C. 2017. Lochkovian to Emsian conodonts (Lower Devonian) at CP-I section. Berichte des Institutes für Erdwissenschaften, KarlsFranzes-Universität Graz 23, 92-98.

Valenzuela-Ríos, J.I., Liao, J-C., Martínez-Pérez, C., CasTelló, V. \& Botella, H. 2005. Datos preliminares sobre los conodontos y restos de peces del Lochkoviense y ¿Praguiense? (Devónico Inferior) de Compte-I (Valle del Noguera Pallaresa, Pirineos), 123-136. In Gámez Vintaned, J.A., Liñán, E. \& VAlenzuela-Ríos, J.I. (eds) La cooperación Internacional en la Paleontología española, Homenaje al Profesor Peter Carls. Institución Fernando el Católico, Zaragoza.

Valenzuela-Ríos, J.I., Slavík, L., Liao, J-C., Calvo, H., HušKovÁ, A. \& Chadimová, L. 2015. The middle and upper Lochkovian (Lower Devonian) conodont successions in peri-Gondwana key localities (Spanish Central Pyrenees and Prague Synform) and their relevance for global correlations. Terra Nova 27, 409-415. DOI 10.1111/ter.12172

VANUXEM, L. 1842. Geology of New York. Part 3, comprising the survey of the third geological district. Natural History of New York 4(3). 306 pp. D. Appleton \& Co. New York.

Von Bitter, P.H. \& Ludvigsen, R. 1979. Formation and function of protegular pitting in some North American acrotretid brachiopods. Palaeontology 22, 705-720.

Waagen, W. 1885. Salt Range fossils, I. Productus-Limestone fossils, Brachiopoda. Memoirs of the Geological Survey of India, Palaeontologica Indica (series 13) 4(5), 729-770.

WiLlard, B. 1928. The brachiopods of the Ottosee and Holston formations of Tennessee and Virginia. Bulletin of the Harvard Museum of Comparative Zoology 68, 255-292.

Williams, A. 2003. Microscopic imprints on the juvenile shells of Palaeozoic linguliform brachiopods. Palaeontology 46(1), 67-92. DOI 10.1111/1475-4983.00288

Williams, A. \& Hurst, J.M. 1977. Brachiopod evolution, 79-119. In Hallam, A. (ed.) Patterns of evolution as illustrated by the fossils record. Developments in Palaeontology and Stratigraphy 5. Elsevier Scientific Publishing Company, Amsterdam. DOI 10.1016/S0920-5446(08)70324-8

ZEzInA, O. 2008. Biogeography of the Recent brachiopods. Paleontological Journal 42(8), 830-858. DOI $/ 10.1134 / \mathrm{S} 0031030108080078$

ZEZINA, O. 2010. Check-list of holocene brachiopods annotated with geographical ranges of species. Paleontological Journal 44(9), 1176-1199. DOI 10.1134/S0031030110090030 